\title{
An electrical experiment
}

\section{Busch}

To cite this article: M. Busch (1886) An electrical experiment, Philosophical Magazine Series 5, 22:137, 388-388, DOI: 10.1080/14786448608627952

To link to this article: http://dx.doi.org/10.1080/14786448608627952

曲 Published online: 29 Apr 2009.

Submit your article to this journal

Џ Article views: 2

Q View related articles $₫$ 
brass sphere 5 inches in diameter. A second thread, similar and parallel to the first, supports a pith ball pendulum, which, when not electrified, is in contact with the brass sphere.

I usually electrify the sphere with the conducting disk of an electrophorus. The extent of the room and the purity of the air enable me to fill the space about the electrified bodies with a considerable quantity of the gas or vapour which I am investigating, without these fluids settling for a time on the long thread. In this way, apart from the small conductivity of the wires, and the losses due to dust in the air, any diminution of the electrical tension observed must have been due to the conductivity of the fluids experimented on.

I always electrified the sphere almost to the same tension; I then observed the time in which the deflection fell a certain number of degrees, first in air and then by surrounding the sphere and the pendulum by a dense atmosphere of the gas to be studied.

I worked thus with air saturated with aqueons vapour at various temperatures from $16^{\circ}$ to $100^{\circ}$; hydrogen and carbonic acid not dried, but as they emerge from the bath in which they are produced; air heated by charcoal or by the flame of a candle, the smoke of an extinguished candle, the fumes of burnt sugar, incense, \&c. None of these substances showed any trace of conductivity.

In one set of experiments, instead of cocoon-threads I used ordinary sewing-thread stretched horizontally, and with a double pendulum in the centre provided with pith balls. The results did not change, but when I worked with aqueous vapour at high temperatures, the divergence diminished rapidly by a certain quantity and then became again almost constant.

This effect is due to the vapour which is deposited on the larger and less insulating wire, and to the fact that the small quantity of electricity of the balls becomes divided between the thread and the balls themselves._Comptes Rendus, Sept. 13.

\section{AN ELEOTRICAL EXPERIMENT. BY M. BUSCH.}

The author calls attention to the curious figures formed when electricity diffuses on a plate previously dusted with lycopodium powder.

The two balls of a Henley's electrometer are brought in contact with two sides of a dusted glass plate, and a large Leyden jar is discharged through the balls. The figure resulting from the discharge has the appearance of a lightning discharge as seen in the photographs of lightning.-Beiblätter der Physik, vol. x. p. 302. 